\title{
On action research and professional development of college English teachers
}

\author{
Jingjing Hao \\ School of Foreign Languages, Qilu Normal University, Ji'nan, 250013, China
}

Keywords: action research; college English teacher; professional development

\begin{abstract}
English teachers have inseparable relevance. Action research theory is an important and effective approach to promote professional development of college English teachers and can smoothly achieve educational objective of college English teachers. Thus, this paper focuses on action research theory to discuss its specific correlation with professional development of college English teachers, points out important significance and value of action research theory for professional development of college English teachers, and proposes reeducation principle and steps of action research in professional development of college English teachers so as to really cultivate college English teachers for rational teaching reflection of college English teachers and better promote their professional growth.
\end{abstract}

\section{Background}

Action research theory was proposed by a British curriculum theory expert and triggers action research tide. Many English teachers also participate in action research process and become researchers and teaching practitioners. In particular, after the problem that who teaches was put forward in 1991, more people start to attach importance to English teacher training and consider English educational reform will become an important link for English teaching to gain further development. Since action research theory still belongs to a new attempt for English education. Therefore, actual English teacher training is still in the exploration phase. Thus, we need to make clear the correlation between action research and professional development of college English teachers, and especially clearly know the important significance and value of action research theory for professional development of college English teachers so as to better apply this theory in English teacher training and really cultivate college English teachers with high quality.

\section{Overview of action research theory}

According to existing definition, many approve the definition of action research proposed by Kemmis and McTaggart. In their opinions, action research means social workers and teaching staffs improve rational cognition and correct evaluation of social or education career through self-reflection. Of course, in essence, it is a relative broad definition. For college English teachers, action research refers to teachers' systematical and reflective exploration activities for their teaching problems. This needs completing through a series of steps. The final propose is o improve teachers' teaching activities, gain better teaching effects and in turn boost teachers' understanding and cognition of teaching process. Generally, action research has three basic features, i.e. classroom, teacher participation and cooperation way. The fundamental objective is to achieve teaching reform. So, action research aims to let college English teachers gradually implement teaching reform plan and promote teaching effect improvement through classroom teaching reform, continuous correction and introspection. Such teaching theory has rational recognition function for college English teachers and can play a significant guiding role for their teaching process. To be more specific, English teachers should firstly discover problems, investigate the cause, then propose a hypothesis, implement the plan, analyze results and provide analysis reports.

\section{Action research and professional development of college English teachers}

Action research as one of important and effective approaches to facilitate professional development of college English teachers is closely related to professional development of college 
English teachers. In fact, teachers' professional development mainly refers to teachers' professional growth or continuous renewal, evolution and richness of internal professional structure, mainly involving improvement and perfection of teachers' professional quality. It is a process of improving teachers' professional self-awareness and takes teachers' education as a main approach. Generally speaking, implementation paths of teachers' professional development include external policy support and internal development demand. Action research mainly depends on teachers themselves. Teachers must actively learn all kinds of teaching theories to improve their problems-solving ability, expand their teaching horizon, boost their teaching level in continuous practice and introspection and finally become an expert teacher. Therefore, in action research, college English teachers become the research subjects, gradually form their own teaching style and facilitate their professional development. In other words, action research and professional development of college English teachers have inseparable relations. The former will impose huge impacts on the latter.

(1) Action research can improve problem consciousness of college English teachers. In the process of action research, college English teachers may boost their problem consciousness. Actually, for college English teachers, their problem consciousness will have direct relation with teaching effects. This is because problem consciousness decides teaching and scientific research ability of college English teachers to some extent. In action research process, the problem to be studied must be first discovered. This is a necessary step and link, and the precondition for any action research. Only when college English teachers discover certain problems can they formulate methods to solve problems and verify them through certain teaching practice so as to effectively promote improvement of English teaching and scientific research ability. Therefore, in action research process, the primary task college English teachers need to complete is to find problems, then rethink and summarize experience of teaching activities in practical class teaching activities, gradually find teaching problems, formulate methods to solve problems, gradually improve professional teaching level according to actual situations, promote their professional development through teaching practice and satisfy teaching ability requirement of current English teaching for college English teachers.

(2) Action research can effectively cultivate reflective ability of English teachers. In action research, reflective ability of college English teachers is an indispensable important ability. In fact, we can say reflection is the core of action research and one of approaches for college English teachers to achieve professional development. Reflection means college English teachers should carry out certain thinking and practice in allusion to their teaching activities, especially review and analyze teaching behaviors and teaching results so as to make teaching theory and teaching practice achieve smooth communication and connection and real communication. In essence, teaching reflection activity itself is one of teaching ways with research nature. It is a process of reflecting, thinking exploring and solving various problems in teaching process, an important approach to improve professional knowledge and ability of English teachers and an important source of continuously enriching teaching attainment of college English teachers. College English teachers continuously adjust their teaching theory and teaching concept through teaching reflection, regard their teaching behavior as the main object of action research to find various problems, continuously review, modify, enhance, eliminate the false and retain the true as much as possible and make teaching activities become an open system and rational teaching process.

(3) Action research contributes to cultivating professional spirit of college English teachers. For college English teachers, their professional spirit has important functions. This is because for college English teachers, their professional development process cannot be separated from high professional spirit. Action research can greatly enhance sense of teaching responsibility of college English teachers so as to more effectively cultivate their professional emotion and high professional dedication. The whole action research process is actually the process in which college English teachers find problems, research and analyze problems as well as positively solve problems through actual teaching activities. Essentially, it reflects good quality and professional spirit of college English teachers. Of course, college English teachers should timely know dynamics and development of English teaching reform in China and foreign countries in action research process, 
pay attention to implementation and progress of school-based education, promote teachers' sense of teaching profession through continuous teaching practice, turn passive teaching activities to active teaching activities, establish teaching professional spirit of a master and become conscious teaching educator.

(4) Action research can promote subject professional development of college English teachers. College English teachers can continuously perfect their professional knowledge structure through action research in teaching activity process, strive to improve their professional theoretical level, and directly apply professional theoretical knowledge in practical teaching process so as to better drive improvement of their practical ability and carry out reflective teaching evaluation. College English teachers can continuously discover defects through their professional teaching activity. In particular, teachers should carefully analyze professional theoretical knowledge and practical ability students most need so as to better guide their professional teaching, improve their professional theoretical attainment and actual teaching practice ability.

(5) Action research is beneficial to promoting college English teachers to combine the theory and practice. College English teachers can organically combine teaching theory and practice through action research and continuously verify teaching theory and develop teaching theory through teaching practice. This is because action research mainly helps college English teachers find all kinds of teaching problems in specific teaching environment. In general, such problem-discovering process can be classified into open research process and directional research process. The former is to find problems, put forward hypotheses and implement the teaching plan through certain teaching practice so as to form a research report during problem solving. The latter refers to a research process of applying brand-new teaching theory or teaching method to adjust related teaching activities in time in specific teaching environment based on others' research results, analyzing and evaluating teaching results or effects, finally confirming whether such teaching theory and method are appropriate. Thus, seeing from the two teaching research forms, college English teachers can really achieve professional development through action research.

\section{Specific application of action research in reeducation of college English teachers}

Action research has certain differences with general researches. It is not a simple data collection and overall analysis process, but means college English teachers can carefully analyze their teaching activities through strict training, gain certain research results through analyzing teaching evidence and examples and apply these research results in teaching work. In this way, teachers cannot just further improve classroom teaching situations, but also really improve their professional quality and teaching ability and finally facilitate their professional development. Of course, in professional reeducation of college English teachers, we should better apply action research theory, make English teachers practically penetrate action research in classroom teaching process and improve teaching effects of the whole class. This requires us well applying action research theory in reeducation process of college English teachers and making these English teachers better master and proficiently apply action research theory.

Specifically, in reeducation of college English teachers, we should adhere to cooperation principle to make each student implement close cooperation, gradually establish an equal relation and organize some cooperative groups to jointly conduct teaching activities. Such teaching group cooperation activity will contribute to them to carry out action research after returning to their original units, finding teaching defects through cooperative work, reviewing their teaching process from the perspective of a third party and gradually correcting their teaching defects and improving professional teaching ability. Besides, in reeducation of college English teachers, we should prepare fully, inducing theoretical preparation, preparation for summarizing teaching experience, visit and training etc., give full play to the functions of English teachers in teaching methodology, and achieve teaching benefits teachers as well as students. In addition, it is necessary to try some brand-new teaching concepts and teaching methods according to the principle of no rush for success, and make college English teachers as reeducation students gain active research participation right and practical research achievements. In reeducation of college English teachers, we should carry out 
action research training according to circulation mode. Thus, we consider we can implement it in six steps, i.e. confirm the starting point, visit the class, exchange and discuss, design improvement scheme, return to classroom and write paper, reconfirm the starting point. It thus can be seen that action research is a circulating process in the process of college English teachers' professional development. Teachers should continuously improve their teaching ability in problem-finding and problem-solving process, make students of action research own large freedom in time arrangement, regard certain tasks as training objectives of action research, guide students to obtain research results through large quantities of practice so as to better cultivate research-oriented teaching teams full of innovation spirit.

\section{References}

[1] Huang Jing, Action research and on-job foreign language teachers [J]. Foreign Language Teaching, 1999(3)

[2] Liang Guojie, Action research of foreign language teachers: achieve professional development in practice [J]. Journal of Liaocheng University (Social Sciences Edition), 2008(2)

[3] Wang Qiang, Action research of English teachers - from theory to practice [M]. Beijing: Foreign Language Teaching and Research Press, 2002:53

[4] Wu Zongjie, Action research: new approach of foreign language normal education [J]. Foreign Language Teaching and Research, 1995(2)

[5] Yu Weishen, Wang Qiang, New trend of English teaching and research from perspective of the $25^{\text {th }}$ conference of International Association of Teachers of English as a Foreign Language [J]. Foreign Language Word, 1999(3) 